\title{
Institutionally Speaking, are Global Standards Adoptable in a Given Jurisdiction? A Critical Analysis of the IFRS's Use in Ukraine through the Lens of New Institutional Accounting
}

\author{
Oleh Pasko ${ }^{1 *}$ \\ ${ }^{1}$ Department of Accounting and Taxation, Faculty of Economics and Management, Sumy National Agrarian University, Herasyma \\ Kondratieva Street 160, 40000 Sumy, Ukraine \\ * Corresponding author, e-mail: oleh.pasko@snau.edu.ua
}

Received: 26 September 2020, Accepted: 27 December 2020, Published online: 19 November 2021

\begin{abstract}
This paper examines the consequences of International Financial Reporting Standards (IFRS) adoption in Ukraine through the lens of New Institutional Accounting theory. IFRS adoption's effects on management's reporting incentives, enforcement and institutional complementarities are analysed. I find that adoption at a technical level is not enough to be called "adoption" as profound changes at the institutional level are also required. Adopted IFRS are subjected to the same type of institutional and market pressures that gave rise to the old set of standards and as a result, the practice of financial reporting is unchanged at its core while only new technical rules apply. Hence, jurisdictions should not pursue only technical adoption but should also try their best to align as close as possible all institutional aspects of this issue. The best advice for all jurisdictions with an institutional infrastructure similar to Ukraine's is to strengthen management's reporting incentives and enforcement mechanisms.
\end{abstract}

Keywords

new institutional accounting, management's reporting incentives, enforcement, institutional complementarities, IFRS, adoption, institutions

\section{Introduction}

The International Financial Reporting Standards (IFRS) have become a veritable lingua franca in global accounting today. The IFRS's publisher the International Accounting Standards Board (IASB) claims that 144 jurisdictions now require the use of IFRS Standards for all or most publicly listed companies, whilst a further 12 jurisdictions permit its use (IFRS Foundation). If we apply less strict parameters such as "permitted but not required for domestic public companies", then only a few jurisdictions, namely Guatemala, Japan, Madagascar, Nicaragua, Panama, Paraguay, Suriname, Switzerland, Timor-Leste are left uncovered, while the overwhelming majority of world countries require or else permit IFRS use (IFRS Foundation). Nevertheless, the question of whether financial reporting practices are comparable is not solved for good as the statistics above describe comparability only in terms of "technical mentality", as we call it, and they do not pay attention to the institutional mechanisms that are operational in the host jurisdiction.
There is a growing number of studies disputing and questioning whether adoption of global standards across jurisdictions has truly taken place, due to "layering of IFRS and Dual Institutionality" (Alexander and Alon, 2017; Alon, 2013), local factors (Alon and Dwyer, 2014; Judge et al., 2010), national patterns of accounting within IFRS (Nobes and Stadler, 2013) and institutional differences between jurisdictions (Daske et al., 2008; Daske et al., 2013; Hail et al., 2010a; 2010b; Wysocki, 2011). The IFRS Project has always developed under the umbrella of harmonisation of accounting practices across the board (Baker and Barbu, 2007) and - later - convergence of accounting standards (Zeff, 2012), but dissenting voices in different guises have derailed even the possibility of uniform adoption of IFRS across the world.

In the last decade, the catchword of IASB has been "adoption" of IFRS, but as Nobes and Zeff fittingly put it there are instances of "adoption that do not deserve the name" (Nobes and Zeff, 2016:p.284). Furthermore, the 
more countries adopt the IFRS "the population of adopters is ... larger and still shows great variety" (Nobes and Zeff, 2016:p.284). There are also so-called "label adopters" companies who adopt IAS just in name without any material changes to their reporting policies (Daske et al., 2013).

The most developed and most significant theory from a research perspective is the theory of New Institutional Accounting, which denies the possibility of comparability of financial statements, even when using the same set of standards, due to differences in reporting incentives, the enforcement mechanisms that are in place and institutional complementarities. Consequently, earlier studies have yielded some tangible results and as of today, we have a developed research area - New Institutional Accounting (NIA) - that deals with the issue of adoption of global accounting standards in a given jurisdiction.

Equipped with NIA terms and methodology I will analyse the way a single country - Ukraine - has gone through the adoption of the IFRS and ascertain to what extent the IFRS in Ukraine have been "adopted" in the way NIA studies understand it at an institutional level. However, unlike the methods previously employed in NIA research, I will use a qualitative approach and rely on interpretative tools. To the best of my knowledge this type of research (a mainly qualitative approach based on one jurisdiction) has rarely been employed in NIA and I am aware of only one similar study (Ball et al., 2003). I would like to emphasise that my interpretative approach was only possible due to the fact that prior studies uncovered some regularities in the adoption of IFRS, and with the help of the established theory of NIA professed by many leading researchers from both sides of the Atlantic.

In contrast to almost all representatives of NIA who have constructed their research based on positivistic tools, and as a rule have employed across-country studies of institutions or descriptive cluster analyses, our approach leans more toward the interpretivist paradigm and is distinctive in its critical analysis of IFRS' adoption in Ukraine: it features one jurisdiction, one country, and longitudinal analysis.

In this paper, I aim to explicate the case of Ukraine and answer the question: did Ukraine adopt the IFRS? And based on Ukraine's case and NIA theory attempt to answer the larger question: institutionally, speaking are global accounting standards truly adoptable? Owing to the similarity of institutional settings in all former post-Soviet countries my results could be applied to other jurisdictions in that area. Hence, in this paper I intend to apply the new institutional accounting approach to a real country case study.
This study contributes to the literature in several ways. It fills in a lacuna concerning Ukraine in the accounting / financial reporting literature, deepening our understanding of those processes in the biggest country in Europe in terms of area. This study also contributes to the literature on the importance of preparers' reporting incentives, as it argues for the necessity of changes in incentives along with the technical standards. The paper also makes a contribution on a descriptive level towards depicting a comprehensive case study of the adoption of the IFRS by a developing country with code law legal system, which is significant as a common law legal system is considered to be a native element for IFRS. The papers also make a contribution to assessing the impact of "new" elements of institutional accounting as opposed to its "hard" or "old" features. It also sheds light on the situation in Ukraine's current accounting, legal and economic systems. Finally, this work contributes to the analysis of the "travel of accounting ideas" (Ezzamel and Xiao, 2011) from developed to emerging economies.

The article is structured as follows. In the next section, I will explicate the main tenets of NIA and its development up to the present day. A brief overview of Ukraine's transition to the IFRS is included in the second section. The third section explicates Ukraine's transformation from national to global accounting standards. The penultimate section is devoted to the elucidation and discussion of Ukraine's transformations in terms of three main aspects of NIA: reporting incentives, enforcement and institutional complementarities. The paper concludes with a discussion.

\section{New institutional accounting theory}

Institutions are seen as mechanisms facilitating economic exchange in society between different actors. Douglas C. North, who alongside Robert W. Fogel got the 1993 Nobel Prize in Economic Sciences "for having renewed research in economic history by applying economic theory and quantitative methods to explain economic and institutional change" (Lennart, 1993), proposed a definition of institutions as the "humanly devised constraints that shape human interaction" (North, 1990:p.3) that provide the "rules of the game in society" (North, 1990:p.3) where the actions of players (organisations) are governed by rules (institutions) (North, 1990).

In a neoclassical economy, as was rightly noted by R. Coase (1960), transaction costs are not accounted for and equal zero. However, a group of authors (Barzel, 1982; Becker, 1965; North, 1981) later indicated that transaction 
costs can be significant if it is difficult to determine the quality and quantity of units to be exchanged when there are problems with the enforcement of the exchange. If this is the case, economic actors have incentives for opportunistic behaviour, which is, after all, a barrier to trade and can stifle exchange.

Institutions, therefore, emerge to reduce and combat opportunistic behaviour and to increase trade benefits. Institutions can significantly reduce transaction costs, lower information and information asymmetry costs, lower coordination costs, secure ownership, and prevent other potential market failures (Alchian and Demsetz, 1972; Coase, 1937).

On the other hand, when there is a great accumulation of different institutions and many interconnections between them, it takes a great deal of effort to bring this system to a working condition and moreover, to enforce it. This could result in the extended power of state authority and create opportunities for some influential actors to take advantage of situations for their own benefit and this, in turn, may lead to the same results inherent to a society without institutions - inefficient contracting (Wysocki, 2011).

So, both situations - when institutions are fledgling or lacking, or when there is excessive state involvement - are unhealthy; in practice, one has to balance the trade-off that exists between the two extremities of disorder, i.e. the costs of opportunistic behaviour in economic exchanges and dictatorship, i.e. the costs of state control with its unequal distribution of coercive power (Djankov et al., 2003).

The term "new institutional accounting" (NIA) is used to describe relatively recent (the early 2000s) research advances made in studying the interactions of market forces, laws, regulations, standards, enforcement activities and other "institutions" and how they affect corporate financial reporting and disclosure outcomes (Leuz and Wysocki, 2016).

NIA is a strain of research which explores "the determinants, outcomes, and interplay between reporting and other non-reporting institutions, mostly in cross-country comparisons" (Leuz and Wysocki, 2016:p.595). This branch of studies analyses the associations of non-reporting institutional variables (which include legal systems, the properties of other legal institutions, capital market features, political systems, the tax system and enforcement, cultural features and corruption) and international differences in disclosures and reporting practices. NIA examines various aspects of countries' financial reporting systems, which include accounting standards, securities and disclosures regulation, reporting enforcement, and audit enforcement.

NIA arose as a critical response to the widely held belief and approach professed by the IASB that uniform global standards are preferable to disparate standards across jurisdictions. The spread of IFRS around the globe has always been justified by improvements in reporting quality and the comparability of financial reporting across firms and countries, but NIA researchers dispute it.

NIA proponents reject those arguments as "it is not obvious, nor has it been empirically documented, that one set of mandated global accounting regulations, let alone the specific standards that comprise IFRS, are superior to other standards and that uniform standards are preferred to other possible scenarios" (Leuz and Wysocki, 2016:p.594).

NIA avers that it is insufficient to just adopt a set of standards to be able to assert that accounting and financial statements are harmonised as "the determinants and outcomes of both accounting institutions (including IFRS) and non-accounting institutions are fundamentally intertwined" (Wysocki, 2011:p.322). There need to be some complementary institutions to support the effective application and enforcement of uniform global standards. Often, the absence of such institutions leads to results that are the opposite of what was intended as "there is an inherent interdependency and complementarity between reporting and non-reporting institutions in each country" (Leuz and Wysocki, 2016:p.595).

The proponents of NIA are adamant that "the presence of other man-made institutions that affect the supply of, and demand for, financial information. These other institutions include the legal system, corporate governance mechanisms, and the existence and enforcement of laws governing investor protection and disclosure standards" (Wysocki, 2011:p.312).

NIA researchers maintain that the importance of accounting standards for the quality of corporate reporting "is more limited than often thought. Other supporting institutions play an important role in determining reporting outcomes. Academic studies suggest that firms' underlying economics and managerial reporting incentives, as well as the enforcement of standards, are at least as important as accounting standards in influencing reporting practices" (Hail et al., 2010a:p.386).

It is worth noting that new institutional accounting theory is a theoretical construction combining the "hard" or "old" institutional approach (as is the case for example with institutional complementarities and partly enforcement 
professed by NIA) and a new institutional approach evident in the analysis of the reporting incentives of companies and individuals.

This new institutional approach manifests itself in emphasis on practice as opposed to theory. NIA proponents argue that even assuming that the country has adopted standards at a given point in time, the assumption that their practices will be harmonised over time is questionable (Hail et al., 2010a; Leuz, 2010; Leuz and Wysocki, 2016; Wysocki, 2011). That is because this new set of standards will be subjected to the same type of institutional and market pressures that gave rise to the old set of standards. Inevitably, the newly adopted sets of standards will drift apart over time due to local factors especially if "the new, harmonised standards are not a good fit for the other institutions" (Leuz and Wysocki, 2016:p.595). It therefore follows that, despite the global convergence in reporting standards, convergence in reporting practices is scarcely attainable (Hail et al., 2010a; Leuz and Wysocki, 2016; Wysocki, 2011).

There are three salient points from NIA framework, namely:

1. reporting incentives;

2. the enforcement mechanism and

3. complementarities and analysis of the institutional environment.

\subsection{Reporting incentives}

NIA's assertion about incentives could be linked to D. North (1990) who argued that institutions are "the rules of the game" that define the incentives for members of the society. The main NIA hypothesis is that "actual reporting changes are ultimately driven by changes in the underlying incentives" (Daske et al., 2013:p.498); again, the emphasis is on practice as opposed to mere theory. Management's reporting incentives are a proxy for assessing the underlying motivations for the accounting change. When reporting incentives are unchanged or have undergone only slight adjustments, then there are no reasons to expect any momentum in terms of changes to "accounting on the ground".

Ball et al. (2003) showed that even countries with high-quality accounting standards may have large differences in reporting quality due to differences in institutionally grounded incentives.

As Nobes and Stadler fittingly remarked "even if all entities are complying with IFRS, the incentives of preparers and enforcers remain "primarily local"" (Nobes and Stadler, 2013:p.574). Preparers are grounded in local habits, traditions, and culture while at the same time they are forced to adopt international standards which are often inherently underpinned by different sets of values.

However, we are obliged to broaden our circle of incentive holders and to include in our analysis not only preparers' incentives but those of auditors. Karampinis and Hevas pointed out the factors that can create an "unfavourable environment" for IFRS adoption and "undermine managers' and auditors' incentives for high-quality financial reporting" (Karampinis and Hevas, 2011:p.304).

Thus, incentives are very important as "incentives dominate [IFRS] in determining accounting quality" (Ramanna and Sletten, 2009:p.29), but so far "preparer incentives have received insufficient attention in the analysis of such issues" (Ball et al., 2003:p.261).

Ball et al. are unequivocal that "it is misleading to classify countries by standards, ignoring incentives, as is common in international accounting texts, transparency indexes, and IAS advocacy" (Ball et al., 2003:p.236). That is why the main hypothesis of NIA is that "the observed economic consequences around IAS adoptions depend on management's reporting incentives, including the underlying motivations for the accounting change, rather than the change in accounting standards per se" (Daske et al., 2013:p.497). Even broad macro institutions (like legal systems, where the distinction between common law and code law is noteworthy) can be shown to influence firms' reporting practices (Ball et al., 2000).

Some authors also analyse political incentives, observable in instances such as the withholding of bad news during periods of political uncertainty, or the withholding of good news and release of bad news around the peak time of the anti-corruption campaign in China (Wang and $\mathrm{Gu}, 2019$ ).

Which factors play a role in incentives formation? There is a common position here that preparer incentives depend on "the interplay between market and political forces in the reporting jurisdiction" (Ball et al., 2003:p.236).

Hail et al. describe these forces in detail:

1. a country's legal institutions, e.g., the rule of law;

2. the strength of the enforcement regime, e.g., auditing;

3. capital market forces, e.g., the need to raise outside capital;

4. product market competition;

5. a firm's compensation, ownership and governance structure, and

6. its operating characteristics (Hail et al., 2010a). Wysocki further adds

7. a country's "baseline factor endowments" (Wysocki, 2011:p.315). 


\subsection{Enforcement}

According to the Standard no. 1 on financial information ("Enforcement of standards on financial information in Europe"), enforcement may be defined as: "monitoring compliance of the financial information with the applicable reporting framework; and taking appropriate measures in case of infringements discovered in the course of enforcement" (The Committee of European Securities Regulators, 2003:p.2).

Brown and Tarca identify three major components of the enforcement process:

1. effective company control systems and management dedicated to good reporting,

2. independent auditors who are experts on the rules, and

3. an oversight mechanism with sufficient expertise and power to achieve effective enforcement (Brown and Tarca, 2005).

NIA shows that both legal and enforcement institutions in a country are important determinants of corporate reporting quality (Leuz et al., 2003).

The enforcement activities of tax authorities and the development of the auditing profession can affect financial reporting properties and disclosure outcomes (Wysocki, 2011). Empirical studies have noted and confirmed that written legislation may be similar or even better than in Western European countries, but their implementation in terms of enforcement mechanisms being put in place is rather inefficient (Albu et al., 2017).

Enforcement is a vital part of what needs to be fixed since "the unsophisticated users of financial reports, the low level of enforcement or the poor investors' protection laws are some of the institutional features characterising many of the CEE countries" (Albu et al., 2017:p.254).

Hail et al. stressed that stricter enforcement and better reporting incentives "imply that firms are less likely to get away with adopting IFRS merely as a label, i.e., without materially changing their reporting practices" (Hail et al., 2010a:p.363). Moreover, it is established that "the capital market benefits exist only in countries with strict enforcement regimes and in institutional environments that provide strong reporting incentives" (Hail et al., 2010a:p.365). That is why a stricter enforcement mechanism generally leads to a lower cost of capital (Wysocki, 2011).

However, it should be stressed that when I refer to new institutional accounting, this does not just mean public enforcement. Public enforcement is complemented by strong private enforcement (as is the case, for example, in the USA), threatening litigation, and potentially huge monetary penalties for managers, directors, and corporations that engage in reporting fraud and misdeeds (Hail et al., 2010a).

New institutional accounting goes far beyond mere proper enforcement of the accounting standards because strict enforcement only limits the amount of discretion that managers have and does not eliminate it (Hail et al., 2010a).

Hail et al. claim that even in a hypothetical world with perfect enforcement, observed reporting behaviour "will differ across firms as long as the accounting standards offer discretion, and there are differences in reporting incentives across firms" (Hail et al., 2010a:p.360).

\subsection{Complementarities}

When "many institutional elements tend to move together and are observed as "bundles"" (Wysocki, 2011:p.314) then we can talk about complementarities.

"The existence of complementarities between institutions implies that countries with different endowments of institutions are likely to select different accounting standards. As a result, historical differences in accounting standards across countries existed because of the corresponding variation in related institutions across countries. The complementarities between various accounting and non-accounting institutions also suggest that changes to a country's accounting standards cannot be considered in isolation from other institutions in a country. In other words, a change in accounting standards may make a country's overall economy worse off even though the proposed accounting change may, in isolation, seem beneficial for corporate financial reporting quality" (Wysocki, 2011:p.318).

\section{Ukraine's transformation from national to global accounting standards}

Ukraine is a country of the former Soviet Union, which in 1991 has regained its independence and has begun to carry out economic reforms aimed at building a market economy. These efforts have had a variable effect, as Ukraine ranked in 2018 as $58^{\text {th }}$ in the world in terms of the sheer volume of its GDP (The World Bank). For analysis purposes, I believe that it would be fair to specify periods of institutional development of accounting and financial reporting in Ukraine that commence after the country regained independence in 1991. 1991-1999 - the continuation of the old mechanisms or, as P. Bourdieu would say, the formation of a new Habitus (Bourdieu and Wacquant, 2013). 20002011 - the emergence of national accounting standards that 
determined what the financial statements were. National standards were strictly based on international standards. 2012 - Transition to IFRS for a large number of enterprises and the requirement for their mandatory application.

Initially, Ukraine had several paths to pursue in terms of IFRS implementation:

1. the application of IFRS as national standards as it is;

2. Developing national accounting standards based on IFRS;

3. Developing national accounting standards autonomously from IFRSs (Pasko, 2011).

At the outset, Ukraine chose a path to develop national Accounting Standards (Standards) based on basic IFRS concepts. The first step was the adoption by the Resolution of Cabinet of Ministers of Ukraine from 29.10.1998 which specified programmes of reforming the accounting system using international accounting standards (Cabinet of Ministers of Ukraine, 1998). This document attributed "the creation of a system of national regulations (standards) for accounting and reporting that will provide the necessary information to users, especially investors" and "ensuring linkage of accounting reformation with the main tendencies of harmonisation of standards at the international level, together with the state of the economic and legal environment and market relations in Ukraine" (Cabinet of Ministers of Ukraine, 1998).

On January 1, 2000, the Law of Ukraine came into force "On Accounting and Financial Reporting in Ukraine", which set out the main provisions of accounting and reporting, legally establishing the rights of all user groups to get accurate information about business activity through accounting and reporting according to the National accounting regulations (standards) that cannot contravene international standards. This was the second stage of IFRS implementation in Ukraine (Law of Ukraine, 1999).

The next - and third - step was the government decision to implement international accounting standards by adopting the State Securities and Exchange Commission of the stock market decision No. 112 of 04/01/2003 on "Guidelines for the transformation of financial statements of Ukrainian enterprises in IAS financial statements". The State Commission on Securities and Stock Market decided to recommend the regulation to issuers whose securities are admitted to trading in organised markets, professional stock market participants, putting into practice the methodological recommendations on the transformation of financial statements of Ukrainian enterprises into financial statements for IAS (SCSSM, 2003).
In June 2011, the Verkhovna Rada, the parliament of Ukraine, adopted amendments to the Law "On Accounting and Financial Reporting in Ukraine". According to these amendments public joint-stock companies, banks, insurers, as well as enterprises carrying out economic activities by types, the list of which is determined by the Cabinet of Ministers of Ukraine had been compelled to prepare the financial statements and consolidated financial statements by international standards only.

The next stage was the adoption by the Cabinet Ministerial Order of February 222012 No. 157-p. "On Creating Conditions for the Implementation of International Financial Reporting Standards" (Cabinet of Ministers of Ukraine, 2012). According to this order, the Ministry of Finance should ensure that the International Financial Reporting Standards are officially published and that they are consistent with the original and have been updated in a timely manner, and in addition approve, by April 1, 2012, guidance on tax filing with enterprise income tax using accounting data and compliance International Financial Reporting Standards. This was a very important watershed moment as, first of all, from now on, financial statements and tax statements would be merged in one and secondly, IFRSs according to amendments are considered those standards that are formally published on the website of the Ministry of Finance of Ukraine (Ministry of Finance of Ukraine, 2020), so effectively from this point, Ukraine's approach morphed to "adoption of IFRS as they are". At that point, and up to now in practice, the standards used in Ukraine differ from IFRS only to the extent that there is a translation lag affecting the use of language. It should, however, be borne in mind that at this time financial reporting in accordance with international standards was not compulsory for all enterprises, but only for certain groups of them.

The next step was the adoption of the Ministry of Finance Order of 07.02.2013 No. 73 on approval of the new National Accounting Standard (NAS) 1 "General Financial Reporting Requirements" (Ministry of Finance of Ukraine, 2013), which replaced Accounting standards 1, 2, 3, 4 and 5 , which had previously and separately determined the order of submission of each of the main forms of financial reporting. The changes were intended to bring accounting and financial reporting in accordance with national standards closer to international accounting standards.

Before the enactment of NAS 1, entities that prepared financial statements according to international standards used the same form (blank) as those companies using national one. The only difference was the mark that was 
put at the top of the form, stating that it is completed in accordance with international standards!

Institutional adoption occurred but encountered considerable difficulties, as not only the provisions of the international standards but also the concepts themselves were new to accountants in Ukraine. A very heated discussion was held, for example, on fair value as opposed to historical value. Unaccustomed to the freedom of action offered by IFRS, Ukraine's accounting communities were at a loss regarding what to do and they sought clarification from the state authorities as in the past, they had received not standards but clear rules delineating every move.

Thus, adoption at the level of "technical mentality" has been dealt with, but what about the bigger picture, taking into account underlying institutional differences? This I will call "institutional adoption" and it is analysed in the next section.

\section{Analysis of Ukraine's transformation through the lens of NIA}

A former socialist country, with code law and fledgeling market economy, Ukraine was hardly a good institutional fit for IFRS. Consequently, from the start in Ukraine there was an "unfavourable environment" for IFRS adoption (Karampinis and Hevas, 2011).

An analysis of Ukraine's transformation through the lens of NIA may usefully start with the question: Why has Ukraine striven to adopt IFRS in the first place? We identified several points that reoccurred constantly in the authorities' rhetoric:

1. there was no reason at all to autonomously develop something that has already been developed elsewhere in the world;

2. IFRS represent great transparency in reporting and that would be instrumental in attracting foreign investment;

3. adoption of IFRS would significantly ease the financial reporting requirement for international companies already operating in the country;

4. IFRS at home would be conducive for local companies to quote their share on a foreign stock exchange. There was also institutional isomorphism, as global institutions like World Bank and IIMF insisted upon the adoption of IFRS as a condition for the granting of financial aid.

So, as we can see the technical mentality prevails, the motto being: we will adopt the new international standards, and everything will change immediately. However, from the perspective of New Institutional Accounting and the Institutional Economy, some institutions can be changed fairly quickly (historically) over 20 years, and some institutions take a long time to change.

So how did Ukraine's transformation fare if we look at it through the lens of NIA theory? We can choose two starting points - from 2000 or 2011 - but in any case, there is no major difference between these periods, the only distinction being that from 2000 to 2011, there was a gradual adoption of IFRS through alignment with the principles laid down in national Ukrainian standards. Thus, from this point on "before" should be taken to refer to the state of affairs before 2011, and "after" to mean post-2011. The analysis that now follows considers the situations that obtained before and after this year using the main tenets of NIA.

\subsection{On incentives}

Two major forces influence incentives: market forces and political forces. Market forces play their part in forming reporting incentives through the demand for high-quality financial reporting. Some of the indicators at play here are the amount of publicly traded equity, the size of the market for public debt, and the extent of private versus public contracting in the economy.

The trading volumes on Ukrainian stock exchanges are low, amounting in 2018 to 19.8 per cent of Ukraine's annual GDP in 2017 - 15.7 (NSSMC, 2018). Moreover, predominantly (69\% in 2018 and 55\% in 2017) it is trade with Ukrainian domestic government bonds (NSSMC, 2018). There is a handful of companies local to Ukraine but with a listing on a foreign stock exchange (Pasko et al., 2019). If companies want to raise funds, they go abroad, not the Ukrainian stock exchange.

Fledgling stock infrastructure is also to blame for market forces having only weak incentivising potential. For example, in their study Daske et al. (2013) categorised three types of indicator to identify major changes in firmlevel reporting incentives, namely input-based incentives, output-based incentives, and lastly, scrutiny by analysts and markets, a factor which significantly shapes management's reporting incentives (Daske et al., 2013). The third indicator - scrutiny by analysts and markets - is badly needed in Ukraine as it does not exist as a category at all.

Some authors claim that "political incentives are prevalent in emerging markets' firms" (Wang and Gu, 2019), but since Ukraine has a historic tradition of democracy, political incentives have never played the kind of role that they do in China, for example - a traditional and collective society. The first Ukrainian constitution so-called the 
Constitution of Pylyp Orlyk was signed on 5 April 1710 and it is considered to be the first European constitution which is based on the democratic principles of the state structure (Vaščenko, 2019). We do not experience any political incentives in Ukraine and we do not know of examples of financial statements being prepared in such a way as not to aggravate the political situation.

In Ukraine, there is another reason why incentives to prepare financial statements are weak: weak market pressure. Today, most, and perhaps the vast majority, of companies make financial statements because the state authority, in the guise of the appropriate bodies, requires it of them. Consequently, financial reporting in Ukraine is simply a tool of statistics, whereas in a market environment it is a tool of competitive advantage. That is why some principles of preparation of financial statements are misinterpreted in Ukraine. For example, there exists a principle in accounting known as prudence, which means that one should apply such asset evaluation methods that would prevent the underestimation of liabilities and expenses and the overestimation of assets and income. The Ukrainian accountant in his/her local mentality often considers the opposite option: overestimation of liabilities and expenses and the underestimation of assets and income. Things are "the other way around", but why? The answer is simple: a Ukrainian accountant, whose mentality (an informal institution, by the way) has been formed in prior conditions is accustomed to preparing financial statements in such a way as to reduce taxable income, meaning that he/she is keen to overestimate liabilities and expenses and underestimate assets and income, not the other way around. In a market economy, when reporting is a tool of competitive advantage, incentives work in the opposite direction - the higher the profit, the better. And the market teaches this, but it does require a true market economy with a strong stock market and strong competition.

The fact that the adoption of international standards was said to have taken place by apologists for the "technical mentality" can be demonstrated by one simple observation. Before national financial reporting provisions came into force, companies that submitted financial statements following international standards and those who did so by Ukrainian standards did so in a single format. How, then, did they differentiate according to which conceptual approach financial statements were prepared? The answer is ridiculous: by a tick in the appropriate box. This again emphasises the striking difference between the mentality or habitus (in P. Bourdieu's terminology) of Ukrainian accountants and the mentality inherent in IFRS. Here, we emphasise that IFRS does not provide a format, and there is only a minimum of items that should be included in the financial statements and required financial statements to be submitted in an appropriate format, something which runs counter to the spirit of international standards.

Professional judgment is a term often used in IFRS. It is a fundamental term because IFRS are based on principles. When in doubt, we should turn to the principles and apply professional judgment. But professional judgment represents a form of freedom, and freedom according to E. Fromm (1994) is what a person wants to escape from. And in the previous example, we can trace this desire to escape from freedom.

What I have described here applies to most, the vast majority of companies; however, for the sake of fairness, it should be noted that there are several Ukrainian companies listed on international stock markets and, accordingly, the financial reporting incentives that apply to them were created by this foreign environment; moreover, very often the internal preparers of financial reporting in those companies (CFOs) have been schooled in IFRS, as they are from Western countries.

To summarise, incentives are only weakly developed, which means that significant efforts still need to be made to bring about true IFRS adoption in Ukraine. To come about, this true adoption must be reflected primarily in the development of market incentives for financial reporting.

\subsection{On enforcement}

Concerning enforcement, the first thing to be mentioned is that in Ukraine it is possible to speak only of public enforcement, as any attempt at private enforcement has little hope of success due to the weak state of the judicial system. There are three level of enforcement:

1. effective company control systems and management dedicated to good reporting,

2. independent auditors who are expert in the rules, and

3. an oversight mechanism with sufficient expertise and power to achieve effective enforcement (Brown and Tarca, 2005).

The first level of enforcement, the internal level, is a function of the incentives for financial reporting. Consequently, if the incentives for financial reporting are weak, the internal level of enforcement is also weak.

As for the second level, here is a very accurate quote which, although it refers to all Central and Eastern European countries, describes perfectly the situation 
in Ukraine: "We propose that the auditors' role is more important when other enforcement mechanisms ... are weak or almost non-existent" (Albu and Albu, 2012:p.349). In this author's opinion, this level is the best component of enforcement. Ukraine was the first of the former Soviet Union countries to switch to International Auditing Standards, which have been national auditing standards in Ukraine since 1997, and audit is performed according to them. In my view, the effectiveness of this second component justifies assigning regulation in this area to professional organisations, and not the state.

Concerning the third level of enforcement, Ukraine uses enforcement by the Stock Exchange Regulator as a type of institutional oversight mechanism, according to Brown and Tarca classification (Brown and Tarca, 2005). The National Commission on Securities and the Stock Market is a state collegiate body subordinate to the President of Ukraine and accountable to the Verkhovna Rada of Ukraine.

The third level of enforcement is constantly being improved, but in my opinion, the level is still insufficient.

\subsection{On complementarities}

Out of the three main elements of New Institutional Accounting theory, the most complicated in Ukraine's case is the situation with complementarities, since the institutional inheritance that Ukraine received from the Soviet Union and its subsequent sporadic way of correcting it has led to a confusing system, and the accumulation of various institutions.

However, up to now we still do not fully understand what is meant by "the necessary or sufficient set of institutions to truly implement IFRS" (Wysocki, 2011:p.323). What is clear, however, is that "if a country does not have strong supporting institutions, then financial reporting is likely to be ineffective in the country" (Wysocki, 2011:p.323). The presence of a code law environment, a top-down regulation mentality, and the generally low level of competition are hardly conducive for IFRS to flourish as these conditions epitomise the very opposite of an environment lending itself naturally to IFRS.

A simple example of complementarities concerns the use of the concept of "the public interest". The concept of the public interest goes hand in hand with IFRS in the Western model (Dellaportas and Davenport, 2008), but at the same time, it is not mentioned in Ukrainian legislation or any regulatory acts or standards at all. Can the accounting profession function properly if it does not serve the public interest?
The question is, of course, rhetorical, but it clearly emphasises the important roles played by different institutional mechanisms and the possible interplay between them.

In closing, based on NIA pillars and on my analysis of IFRS adoption in Ukraine I will now summarise my findings using a comprehensive model; Fig. 1 depicts the logical framework model of IFRS adoption within a particular jurisdiction.

The logic here is that the same technical standards adopted in a particular jurisdiction will inevitably lead to unique reporting practices. Moreover, as has already been noted, the broader IFRS proliferate, the greater the variation will be among these practices. While they may be adopted simultaneously, standards can only be adopted, over time, under the influence of local institutional features. Consequently, unique local practices will be created due to differences in reporting incentives, enforcement mechanisms and institutional complementarities.

\section{Discussion and conclusions}

This paper examined the consequences of International Financial Reporting Standards (IFRS) adoption in Ukraine through the lens of new institutional accounting theory. The effects of IFRS adoption on management reporting incentives, enforcement and institutional complementarities were all analysed. I found that Ukraine preparers' reporting incentives imply low quality; Ukraine has no strict enforcement mechanism and no strong market-based reporting incentives already in place (two main components of NIA). Hence, it can be concluded that adoption on a technical level is not enough to be truly called "adoption", since profound changes on the institutional level are also required. Once adopted, IFRS are subjected to the same type of institutional and market pressures that gave rise to the old set of standards and as a result, the practice of financial reporting in Ukraine remains essentially unchanged while only new technical rules apply. To improve matters, jurisdictions similar to Ukraine should not only pursue technical adoption but should also strive to align as closely as possible all the institutional aspects of this issue. Reporting incentives, enforcement and complementarities are closely intertwined and should not be considered as separate items. Reliable financial reporting will only come together with strong enforcement/reporting incentives.

Approaching local practices with a "technical mentality" is not a good way to adopt international standards, and not only those that apply to accounting, to one's local situation as the institutional aspects of such an adoption also 


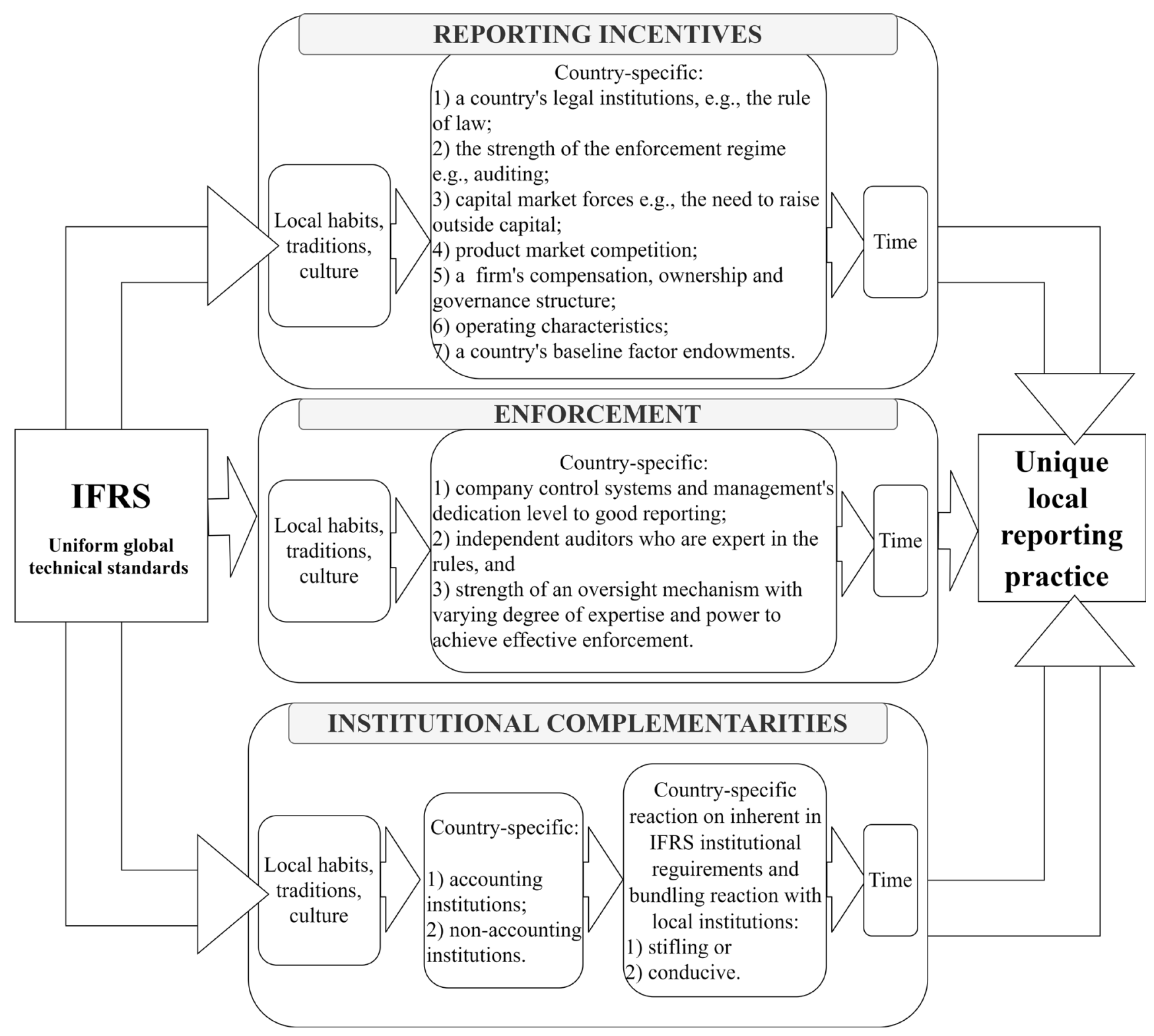

Fig. 1 Logical framework model of IFRS adoption according to NIA

need to be thoughtfully reconsidered. If this is not done, there is a danger that implementation could lead to results that are the very opposite of what was intended.

International standards can be adopted, but the approaches taken to this differ between jurisdictions. Inserted into different institutional settings, they may produce incongruent results. Consequently, institutionally speaking global standards are not truly global, as only part of them can be adopted "close" to expectations, whereas another part will be adopted only as closely as local institutions allow it. IFRS are adoptable, but in the course of this adoption, changes occur that inevitably lead to the incomparability of the financial statements across jurisdictions. So can we say that implementations of international standards comparable? In terms of technical mentality, the answer will be yes, but in terms of institutional accounting the answer is no, such comparability is not possible, as demonstrated by the experience of Ukraine.

In pure theory, the adoption of IFRS should have led to an improvement to the increased quality of financial reporting; however, again, this is true only if we apply a "technical mentality". If we instead apply an "institutional mentality", we should take into account the practice of financial reporting, which has not changed significantly. Adopted IFRS have been subjected to the same type of institutional and market pressures that gave rise to the old set of standards and as result, international convergence in reporting practices is scarcely attainable. Again, the emphasis is on practice as opposed to merely theory, and on attention to institutions. If, as in Ukraine, 
reporting incentives are unchanged or have undergone only slight adjustments then there are no reasons to expect any momentum in terms of changes to "accounting on the ground". Adopted IFRS does not change the fact that the incentives of preparers and enforcers remain "primarily local" (Nobes and Stadler, 2013:p.574).

The quality of financial reporting and its comparability ultimately depend on management's reporting incentives. The best advice for all jurisdictions that are similar to Ukraine in terms of institutional infrastructure would be to strengthen management's reporting incentives. The financial reporting incentives need to be changed, and the institutions that form them have to be changed gradually. Due to the existence of complementarities, changes to a country's accounting standards cannot be considered in isolation from other institutions in a country.

Hence, technical adoption of IFRS is possible, but proper institutional adoption remains an unaccomplished feat. Once again, we can say that we can adopt IFRS,

\section{References}

Albu, N., Albu, C. N. (2012) "International Financial Reporting Standards in an Emerging Economy: Lessons from Romania", Australian Accounting Review, 22(4), pp. 341-352. https://doi.org/10.1111/j.1835-2561.2012.00196.x

Albu, N., Albu, C. N., Filip, A. (2017) "Corporate Reporting in Central and Eastern Europe: Issues, Challenges and Research Opportunities", Accounting in Europe, 14(3), pp. 249-260. https://doi.org/10.1080/17449480.2017.1385819

Alchian, A., Demsetz, H. (1972) "Production, Information Costs, and Economic Organization", The American Economic Review, 62(5), pp. 777-795.

Alexander, D., Alon, A. (2017) "Layering of IFRS and Dual Institutionality of Accounting Standards in Belarus", Accounting in Europe, 14(3), pp. 261-278. https://doi.org/10.1080/17449480.2017.1374547

Alon, A. (2013) "Complexity and Dual Institutionality: The Case of IFRS Adoption in Russia", Corporate Governance: An International Review, 21(1), pp. 42-57.

https://doi.org/10.1111/j.1467-8683.2012.00927.x

Alon, A., Dwyer, P. D. (2014) "Early Adoption of IFRS as a Strategic Response to Transnational and Local Influences", The International Journal of Accounting, 49(3), pp. 348-370. https://doi.org/10.1016/j.intacc.2014.07.003

Baker, C. R., Barbu, E. M. (2007) "Trends in research on international accounting harmonization", The International Journal of Accounting, 42(3), pp. 272-304. https://doi.org/10.1016/j.intacc.2007.06.003

Ball, R., Kothari, S. P., Robin, A. (2000) "The effect of international institutional factors on properties of accounting earnings", Journal of Accounting and Economics, 29(1), pp. 1-51. https://doi.org/10.1016/S0165-4101(00)00012-4 yet we cannot adopt it properly. Having global standards enshrined in the country's legislative field is not enough, instead there need to be some complementary institutions to support the effective application and enforcement of uniform global standards. The application of IFRS at a merely technical level becomes meaningless and as a result, standards become increasingly local - the very opposite of the outcome IASB is striving for.

Is there a way out? The way forward is to strengthen management's reporting incentives and enforcement mechanisms through the construction of appropriate formal institutions and the restructuring of informal ones. Although convergence in reporting practices is scarcely attainable, we are obliged to strive to achieve it.

The paper is of course far from the final word on this issue. Future research will need to concentrate on assessing the relative contribution of standards and incentives to the process and the theory of gradual adoption of global standards based on P. Bourdieu's social theory.

Ball, R., Robin, A., Wu, J. S. (2003) "Incentives versus standards: properties of accounting income in four East Asian countries", Journal of Accounting and Economics, 36(1-3), pp. 235-270. https://doi.org/10.1016/j.jacceco.2003.10.003

Barzel, Y. (1982) "Measurement Costs and the Organization of Markets", Journal of law and economics, 25(1), pp. 27-48.

Becker, G. S. (1965) "A Theory of the Allocation of Time", The Economic Journal, 75(299), pp. 493-517.

Bourdieu, P., Wacquant, L. (2013) "Symbolic capital and social classes", Journal of Classical Sociology, 13(2), pp. 292-302. https://doi.org/10.1177/1468795X12468736

Brown, P., Tarca, A. (2005) "A commentary on issues relating to the enforcement of International Financial Reporting Standards in the EU", European Accounting Review, 14(1), pp. 181-212. https://doi.org/10.1080/0963818042000338997

Cabinet of Ministers of Ukraine (1998) "Про затвердження Програми реформування системи бухгалтерського обліку із застосуванням міжнародних стандартів" (On approval of the Program of reforming the accounting system with application of international standards), [pdf] Approved by the resoluton of the Cabinet of Ministers of Ukraine of October 28, 1998, No. 1706, Kiev, Ukraine. Available at: https://zakon.rada.gov.ua/laws/ show/1706-98-п [Accessed: 09 August 2020] (in Ukrainian)

Cabinet of Ministers of Ukraine (2012) "Про створення умов для впровадження міжнародних стандартів фінансової звітності" (On creating conditions for the implementation of international financial reporting standards), Resolution of the Cabinet of Ministers of Ukraine dated February 22, 2012, No. 157-r, Kiev, Ukraine. [online] Available at: https://zakon.rada.gov.ua/laws/ show/157-2012-\%D1\%80\#Text [Accessed: 11 November 2020] (in Ukrainian) 
Coase, R. H. (1937) "The Nature of the Firm", Economica, 4(16), pp. 386-405.

Coase, R. H. (1960) "The Problem of Social Cost", In: Gopalakrishnan, C. (ed.) Classic Papers in Natural Resource Economics, Palgrave Macmillan, London, UK, pp. 83-137. https://doi.org/10.1057/9780230523210_6

Daske, H., Hail, L., Leuz, C., Verdi, R. (2008) "Mandatory IFRS Reporting around the World: Early Evidence on the Economic Consequences", Journal of Accounting Research, 46(5), pp. $1085-1142$.

https://doi.org/10.1111/j.1475-679X.2008.00306.x

Daske, H., Hail, L., Leuz, C., Verdi, R. (2013) "Adopting a Label: Heterogeneity in the Economic Consequences Around IAS/IFRS Adoptions", Journal of Accounting Research, 51(3), pp. 495-547. https://doi.org/10.1111/1475-679X.12005

Dellaportas, S., Davenport, L. (2008) "Reflections on the public interest in accounting", Critical Perspectives on Accounting, 19(7), pp. 1080-1098. https://doi.org/10.1016/j.cpa.2007.06.002

Djankov, S., Glaeser, E., La Porta, R., Lopez-de-Silanes, F., Shleifer, A. (2003) "The new comparative economics", Journal of Comparative Economics, 31(4), pp. 595-619. https://doi.org/10.1016/j.jce.2003.08.005

Ezzamel, M., Xiao, J. Z. (2011) "Accounting in Transitional and Emerging Market Economies", European Accounting Review, 20(4), pp. 625-637. https://doi.org/10.1080/09638180.2011.629798

Fromm, E. (1994) "Escape from Freedom", Holt Paperbacks, New York, NY, USA.

Hail, L., Leuz, C., Wysocki, P. (2010a) "Global Accounting Convergence and the Potential Adoption of IFRS by the U.S. (Part I): Conceptual Underpinnings and Economic Analysis", Accounting Horizons, 24(3), pp. 355-394.

https://doi.org/10.2308/acch.2010.24.3.355

Hail, L., Leuz, C., Wysocki, P. (2010b) "Global Accounting Convergence and the Potential Adoption of IFRS by the U.S. (Part II): Political Factors and Future Scenarios for U.S. Accounting Standards", Accounting Horizons, 24(4), pp. 567-588. https://doi.org/10.2308/acch.2010.24.4.567

IFRS Foundation "Who uses IFRS Standards?", [online] Available at: https://www.ifrs.org/use-around-the-world/use-of-ifrs-standardsby-jurisdiction/ [Accessed: 28 September 2019]

Judge, W., Li, S., Pinsker, R. (2010) "National Adoption of International Accounting Standards: An Institutional Perspective", Corporate Governance: An International Review, 18(3), pp. 161-174. https://doi.org/10.1111/j.1467-8683.2010.00798.x

Karampinis, N. I., Hevas, D. L. (2011) "Mandating IFRS in an Unfavorable Environment: The Greek Experience", The International Journal of Accounting, 46(3), pp. 304-332. https://doi.org/10.1016/j.intacc.2011.07.001

Law of Ukraine (1999) "Закон України: Про бухгалтерський облік та фінансову звітність в Україні" (Law of Ukraine: On Accounting and Financial Reporting in Ukraine), Videmosti Verkhovnoi Rady Ukrainy (VVR), 40, Article number: 365. [online] Available at: https://zakon.rada.gov.ua/laws/show/996-14 [Accessed: 12 August 2020] (in Ukrainian)
Lennart, J. (1993) "Award ceremony speech", [online] Available at: https://www.nobelprize.org/prizes/economic-sciences/1993/ ceremony-speech/ [Accessed: 12 August 2020]

Leuz, C. (2010) "Different approaches to corporate reporting regulation: How jurisdictions differ and why", Accounting and Business Research, 40(3), pp. 229-256.

https://doi.org/10.1080/00014788.2010.9663398

Leuz, C., Wysocki, P. D. (2016) "The Economics of Disclosure and Financial Reporting Regulation: Evidence and Suggestions for Future Research", Journal of Accounting Research, 54(2), pp. 525-622.

https://doi.org/10.1111/1475-679X.12115

Leuz, C., Nanda, D., Wysocki, P. D. (2003) "Earnings management and investor protection: an international comparison", Journal of Financial Economics, 69(3), pp. 505-527.

https://doi.org/10.1016/S0304-405X(03)00121-1

Ministry of Finance of Ukraine (2020) "Translation of International Financial Reporting Standards 2020", [online] Available at: https://mof.gov.ua/uk/mizhnarodni-standarti-finansovoi-zvitnosti [Accessed: 09 November 2020]

Ministry of Finance of Ukraine (2013) "Про затвердження Національного положення (стандарту) бухгалтерського обліку 1 «Загальні вимоги до фінансової звітності»" (Order on approval of the new National accounting standard (NAC) 1 "General Financial Reporting Requirements"), dated 07.02.2013, No. 73, Kiev, Ukraine. [online] Available at: https://zakon.rada.gov.ua/laws/ show/z0336-13\#Text [Accessed: 09 November 2020] (in Ukrainian)

NSSMC (2018) "Річний звіт Національної комісії з цінних паперів та фондового ринку за 2018 рік" (Annual Report of the National Association of Price Markets and Stock Market for 2018), [pdf] National Securities and Stock Market Commision, Kiev, Ukraine, Available at: https://www.nssmc.gov.ua/wp-content/ uploads/2019/08/zvit_2018.pdf [Accessed: 12 August 2020] (in Ukrainian)

Nobes, C., Stadler, C. (2013) "How arbitrary are international accounting classifications? Lessons from centuries of classifying in many disciplines, and experiments with IFRS data", Accounting, Organizations and Society, 38(8), pp. 573-595.

https://doi.org/10.1016/j.aos.2013.10.001

Nobes, C. W., Zeff, S. A. (2016) "Have Canada, Japan and Switzerland Adopted IFRS?", Australian Accounting Review, 26(3), pp. 284-290.

https://doi.org/10.1111/auar.12131

North, D. C. (1981) "Structure and Change in Economic History", Norton, New York, NY, USA.

North, D. C. (1990) "Institutions, Institutional Change and Economic Performance", Cambridge University Press, Cambridge, UK. https://doi.org/10.1017/CBO9780511808678

Pasko, O. (2011) "The role of national accounting regulators in today's world", Accounting and Finance of AIC, 3, pp. 38-50.

Pasko, O., Melnychuk, O., Bilyk, T. (2019) "Ownership concentration, investor protection and economic performance in public agroindustrial companies with the listing on warsaw stock exchange", Independent Journal of Management \& Production (Special Edition PDATU), 10(7), pp. 817-845.

https://doi.org/10.14807/ijmp.v10i7.914 
Ramanna, K., Sletten, E. (2009) "Why do Countries Adopt International Financial Reporting Standards?", Harvard Business School Accounting \& Management Unit, Boston, MA, USA, Working Paper No. 09-102.

https://doi.org/10.2139/ssrn.1460763

SCSSM (2003) "Щодо Методичних рекомендацій з трансформації фінансової звітності українських підприємств у фінансову звітність за МСБО" (Guidelines for transformation of financial statements of Ukrainian enterprises into IAS financial statements), Decision of the State Commission on Securities and Stock Market from April 1, 2003, No. 112. [online] Available at: https://ips. ligazakon.net/document/KML03180 [Accessed: 09 August 2020] (in Ukrainian)

The Committee of European Securities Regulators (2003) "CESR/03-073 Standard No. 1 on Financial Information: Enforcement of Standards on Financial Information in Europe", [pdf] CESR, Paris, France. Available at: https://www.esma.europa.eu/sites/default/ files/library/2015/11/03_073.pdf [Accessed: 09 January 2020]
The World Bank "GDP Ranking", [online] Available at: https://datacatalog. worldbank.org/dataset/gdp-ranking [Accessed: 09 January 2020]

Vaščenko, J. (2019) "Pilypo Orlyko Konstitucija: šiuolaikinès konstitucinès ir administracinès teisès kategorijos" (Constitution of Pylyp Orlyk: Categories of Contemporary Constitutional and Administrative Law), LOGOS, 99, pp. 73-84. (in Ukrainian) https://doi.org/10.24101/logos.2019.31

Wang, X., Gu, X. (2019) "Political incentives in firms' financial reporting: evidence from the crackdown on corrupt municipal officials", Economics of Governance, 20(3), pp. 255-284. https://doi.org/10.1007/s10101-019-00225-3

Wysocki, P. (2011) "New institutional accounting and IFRS", Accounting and Business Research, 41(3), pp. 309-328. https://doi.org/10.1080/00014788.2011.575298

Zeff, S. (2012) "The Evolution of the IASC into the IASB, and the Challenges it Faces", The Accounting Review, 87(3), pp. 807-837. https://doi.org/10.2308/accr-10246 